\title{
The Coronavirus Chasm in Inflammatory Bowel Disease: Report of Patient-Centered Care at a Hospital in Northern Portugal
}

\author{
Paula Lago $^{a}$ Cidalina Caetano $^{a}$ Daniela Ferreira $^{a, b}$ Marta Salgado ${ }^{a, b}$ \\ Isabel Pedroto ${ }^{a, b}$ \\ a Department of Gastroenterology, Centro Hospitalar Universitário do Porto, Hospital Santo António, Porto, \\ Portugal; ${ }^{b}$ Abel Salazar Institute of Biomedical Sciences (ICBAS), University of Porto, Porto, Portugal
}

\section{Keywords}

COVID-19 - Inflammatory bowel disease · Patient-centered care

\section{Abstract}

Introduction: Although patient-centered care can be found in the mission statement of nearly every hospital, it is not always put into practice, and COVID-19 brings new challenges even to the best-organized hospitals and well-developed health care systems. Methods: In the current COVID-19 pandemic, inflammatory bowel disease (IBD) patients have a potentially higher risk of complications from this infectious disease due to the use of immunosuppressant and/or biologic treatments and due to flares of this chronic illness, which often require urgent care and sometimes hospitalization. Moreover, patients undergoing biologic intravenous (IV) treatment visit the hospital for scheduled IV infusions. Discussion: In hospitals like ours, where COVID-19 patients are treated, the organization of "clean circuits" is essential to minimize the risks of infection for non-COVID-19 patients, such as patients in IBD infusion units. In our hospital, the IBD infusion unit is located within the gastroenterology department, which, under normal circumstances, is very advantageous for patients but in the current context is not. Our goal was to maximize adherence to biologic IV treatment and

karger@karger.com www.karger.com/pjg

Karger

BOPEN ACCESS
(C) 2020 Sociedade Portuguesa de Gastrenterologia Published by S. Karger AG, Basel

This article is licensed under the Creative Commons AttributionNonCommercial-NoDerivatives 4.0 International License (CC BYNC-ND) (http://www.karger.com/Services/OpenAccessLicense) Usage and distribution for commercial purposes as well as any distribution of modified material requires written permission. clinical safety at a time of profound changes in gastroenterology activity and in a department with daily increases in the number of COVID-19 patients. Conclusion: To this end, we initiated proactive COVID-19 testing in IBD patients undergoing biologic IV treatment and changed the location of the infusion unit to a "COVID-free" institution, maintaining the care of these patients by the dedicated IBD team of our department. The purpose of this report is to show that a patient-centered care strategy allowed us to reach very high levels of patient comfort, satisfaction, and compliance with therapeutics.

(C) 2020 Sociedade Portuguesa de Gastrenterologia Published by S. Karger AG, Basel

\section{O abismo do Coronavírus na Doença Intestinal Inflamatória: Experiência de um Hospital no Norte de Portugal em cuidados centrados no doente}

\section{Palavras Chave}

COVID-19 · Doença intestinal inflamatória · Cuidados centrados no doente

\section{Resumo}

Introdução: Os cuidados centrados no doente são uma intenção de quase todas as declarações de missão de um 
hospital. No entanto, nem sempre são colocados em prática. A doença por COVID-19 trouxe novos desafios, mesmo para os hospitais mais bem organizados e com sistemas de saúde desenvolvidos. Métodos: $\mathrm{Na}$ atual pandemia COVID-19, os doentes com doença intestinal inflamatória (DII), têm um risco potencialmente maior de complicações desta doença infeciosa, quer pelo uso de tratamentos imunossupressores e/ou biológicos, quer pela natureza crónica da doença, que evolui com agudizações, que frequentemente requerem cuidados urgentes e, às vezes, hospitalização. Os doentes sob biológicos intravenosos (IV) necessitam de recorrer ao hospital para infusão programada. Discussão: Em hospitais como o nosso, onde doentes com COVID-19 são recebidos e tratados, a organização de "circuitos limpos" é essencial para minimizar os riscos de infeção em doentes não-COVID-19, nomeadamente nas unidades de infusão de biológicos. No nosso Hospital, a unidade de infusão localiza-se dentro do Departamento de Gastrenterologia, o que em circunstâncias normais é muito vantajoso para os doentes, mas não o foi no contexto da atual pandemia. O nosso objetivo, num momento de profunda mudança da atividade da Gastrenterologia e num Departamento com aumento diário do número de doentes COVID-19, foi o de maximizar a adesão aos tratamentos biológicos IV e a sua segurança clínica. Conclusão: Para isso iniciamos um programa proactivo de teste a COVID-19, nos doentes com DII, sob biológicos IV, e mudamos a unidade de infusão para uma Instituição "COVID free," mantendo a habitual orientação destes doentes pela equipe diferenciada de DIl do nosso Serviço. O objetivo deste trabalho é mostrar que, com uma estratégia de cuidados centrados no doente, foi possível atingir níveis elevados de adesão à terapêutica, de conforto e satisfação.

๑ 2020 Sociedade Portuguesa de Gastrenterologia Publicado por S. Karger AG, Basel

\section{Introduction}

The Institute of Medicine (as the National Academy of Medicine of the USA was then known) Committee on Quality of Health Care in America stated in their publication Crossing the Quality Chasm [1] that one of the first steps to enhance the quality and safety of health care organizations is the organization and coordination of care around patient needs. The primary purpose of identifying priority conditions is to facilitate the organization of care around the patient's perspective and needs rather than (as in the current system) around professionals and organizations [2].

The Coronavirus Chasm in Inflammatory Bowel Disease
We work in a hospital in the north of Portugal, the most affected COVID area in Portugal, and our institution is one of the reference hospitals for COVID-19 patients (about 350 inpatient admissions for COVID-19 up to April 24, 2020). The "COVID 19: Portugal Update, 25 April" report in 2020 of the Portuguese Health Authorities (DGS) about the epidemiological situation revealed 22,797 confirmed COVID-19 cases in Portugal, and 13,707 of them occurred in northern Portugal (DGS report 53/2020). In the inflammatory bowel disease (IBD) unit of our gastroenterology department, about 1,700 IBD patients are followed up, and $60 \%$ of them are undergoing immunosuppressive and/or biologic therapies. Since the beginning of the COVID-19 pandemic, our IBD patients, and particularly those undergoing immunosuppressive and/or biologic therapies, were anxious about coming to the hospital for scheduled infusions, and some patients wanted to stop treatments in fear of becoming infected and of being at greater risk of serious disease were they infected. The patients undergoing IV biologics must visit hospital for scheduled IV infusions. The International Organization for the Study of Inflammatory Bowel Disease [3] recommends continuing biologic therapies, including infusion therapies administered in hospitals, on the condition that the infusion center provides an adequate screening protocol. In our hospital, the infusion unit is located within the gastroenterology department and is open Monday to Friday 08:30-18.30, with daily support provided by the IBD-dedicated team. Blood and fecal tests are done on the day of the infusion, as are some routine medical consultations. Under normal circumstances, this is very advantageous for patients, but in the current context, it was not. Our goal was to maximize adherence to IV biologic treatment and clinical safety in a time of profound changes in gastroenterology activity and in a department with a daily increasing number of COVID-19 patients.

\section{How to Cross the Chasm?}

One of the most important issues was to calm patients who are in fear of catching a potentially fatal disease: Do I have it? Will I get it if I go to hospital? This unprecedented time put the safety of accessing health systems into question. Patients have never experienced anything like this before in their lives. This doubt can delay accessing care because patients are not immune to the panic surrounding them. 
Our goal was to maximize adherence to treatment by ensuring care that is effective, safe, and a positive experience for patients.

\section{Redesigning Care}

Care for IBD patients during this period was organized around

1 minimizing risks to patients,

2 improving patient experience by calming fears,

3 optimizing the use of resources,

4 standardizing care, and

5 developing efficient workflows.

\section{Materials and Methods}

\section{Structure}

To enhance the quality of care across the continuum, we improved risk-adjusted patient outcomes, promoted patient safety, increased patient satisfaction, and optimized the use of human resources. As it was difficult to have a proper patient flow in our institution, we moved part of the team and patients under IV biologics to another "COVID-free" institution, keeping the patient flow running in an optimized manner. Seats in the infusion room were rearranged approximately $2.5 \mathrm{~m}$ apart, and $\leq 3$ patients at a time were allowed in the room. After hospital admission, patients had direct access via an elevator to the ambulatory center unit. We started with this on April 6, 2020.

\section{Process}

\section{Phone Consultations}

From March 9, 2020, our team of 4 IBD-dedicated gastroenterologists initiated phone calls for all scheduled consultations, thus avoiding unnecessary patient visits to the hospital, providing a safe alternative to face-to-face consultations for a large percentage of our IBD patients. We also implemented phone calls by a dedicated nurse to all IBD patients under biologics to screen for COVID-19 symptoms and to contact infected individuals and in order to emphasize the importance of primary prevention.

\section{COVID-19 Testing}

There was no specific guidance with respect to $\mathrm{CO}$ VID-19 testing in patients with IBD. As the north of Portugal has more than half of the cases nationally, we de- cided to test all IBD patients before therapy and IBD-dedicated professionals working in the IBD infusion unit. In our opinion, it is reasonable to test asymptomatic patients scheduled for immunosuppressive and/or biologic therapy who may be at risk of serious complications from COVID-19. This also affects decisions regarding the protection of health care providers. We started COVID-19 testing in these populations on April 4, 2020.

\section{Coordination of Roles and Activities of the}

Multidisciplinary Team

Communication. A phone call is made 3 days before the infusion by an IBD-dedicated nurse to screen for possible COVID-19 symptoms or make contact with infected individuals, and to inform the patient about the rationale and the decision to perform COVID-19 testing before infusion. The test is scheduled $48 \mathrm{~h}$ before the infusion.

The COVID Team. All tests are scheduled and performed in a drive-in manner for patients with their own vehicle. For patients without a car, the team provides transportation to the drive-in testing site at our hospital. In the case of a positive test, the IV biologic treatment would be postponed until the infection was cured. Patients with a negative COVID-19 test are directed to the infusion unit.

The IBD Team. All the professionals working in the IBD infusion unit were COVID-19 tested before starting work in the unit. One IBD-dedicated nurse and 1 IBDdedicated gastroenterologist work exclusively in the infusion unit for a period of 15 days, after which they are replaced by 2 other IBD-dedicated professionals. The staff members have a mobile phone reserved for calls to IBD patients to make scheduled and unscheduled consultation appointments and to receive calls from patients who have flares or doubts. On admission to the hospital, patients have their temperature tested, and they put on a surgical mask. Before entering the infusion unit, they are evaluated by the IBD gastroenterologist, routine blood tests are performed, and fecal calprotectin is collected before infusion. This strategy takes advantage of the patients' presence in the hospital to maximize the assessment and minimize visits.

The Information System Team. The information system team provides remote access to all clinical information to the IBD team.

The Pharmacy Team. The pharmacy team supplies all the medication; every Monday, all the necessary drugs for the whole week are sent to the pharmacy at the new institution. 
Results

From March 9 to April 24, 2020, we had 457 IBDscheduled consultations, all of which were carried out: $97 \%$ by phone calls and $3 \%$ by face-to-face consultations after prior phone call evaluation.

From April 6 to April 24, 2020, we had 140 patients (122 patients had Crohn's disease and 18 ulcerative colitis; $51 \%$ were males, mean age was 36 years, and $50 \%$ received azathioprine and $10 \%$ methotrexate) scheduled with 140 sessions of IV biologics (infliximab: 123 and vedolizumab: 17), and COVID-19 testing was done on 138 patients, all of which were negative,; 138 IV infusions were performed. Two patients could not be contacted and therefore missed testing and treatment sessions.

\section{Discussion/Conclusion}

\section{Patients}

The patients felt calm, comfortable, cared for, and safe, and most did not miss any test, treatment, or scheduled consultation.

\section{Professionals}

This COVID outbreak gave the professionals the opportunity to rethink the quality and safety measures and to recreate new effective approaches:

1 To remove some barriers, for example against phone consultations, which we realized can be utilized with some patients and provide high-quality care.

2 To be prepared for the future, including the time after the pandemic.
The future of health care depends on technology, good management, and flexibility in the workplace. We have learned that new challenges recreate health care, and we all have to be flexible and focused to get not only through COVID-19 but to be prepared for what may happen afterwards.

With a proactive COVID-19 test strategy in this IBD population, it was possible, at this stage, to give safety to the patient, to avoid infusion of biologics in asymptomatic but positive COVID-19 patients, and to avoid transmission to other patients and health care professionals.

\section{Statement of Ethics}

All rules of the local ethics committee were followed, preserving patient identity and confidentiality.

\section{Conflict of Interest Statement}

The authors declare that there are no conflicts of interest associated with this publication, and there has been no financial support.

\section{Author Contributions}

Isabel Pedroto and Paula Lago were responsible for the study conceptualization, manuscript original drafting, editing and review, and project administration.

Marta Salgado, Cidalina Caetano, and Daniela Ferreira were responsible for project administration and manuscript review.

\section{References}

1 Institute of Medicine (US) Committee on Quality of Health Care in America. Crossing the Quality Chasm: A New Health System for the 21st Century. Washington (DC): National Academies Press; 2001.
2 Vanhaecht K, Panella M, Van Zelm RT, Sermeus W. Is there a future for pathways? Five pieces of the puzzle. Int J Care Pathways. 2009; 13(2):82-6.
3 Rubin DT, Abreu MT, Rai V, Siegel CA, Ahuja V, Allez M, et al; International Organization for the Study of Inflammatory Bowel Disease. Management of patients with Crohn's disease and ulcerative colitis during the COVID-19 pandemic: results of an international meeting. Gastroenterology. 2020 Jul;159(1): 6-13.e6. 